\title{
Association of serum calcium concentrations with renal impairment in Chinese patients with newly diagnosed multiple myeloma: A Retrospective Study
}

Jun Cheng

Zhejiang University School of Medicine

\section{Yi Zhao}

Zhejiang University School of Medicine

Wen zhang

Hangzhou Red Cross Hospital

\section{Xiayu Li}

Zhejiang University School of Medicine

\section{Rong Lv}

Zhejiang University School of Medicine

heng Li

Zhejiang University School of Medicine

Chen Jianghua ( $\nabla$ chenjianghua@zju.edu.cn )

Zhejiang University School of Medicine https://orcid.org/0000-0002-3282-3998

\section{Research}

Keywords: multiple myeloma, Renal impairment, serum calcium concentration

Posted Date: December 20th, 2019

DOI: https://doi.org/10.21203/rs.2.19392/v1

License: (c) (1) This work is licensed under a Creative Commons Attribution 4.0 International License. Read Full License 


\section{Abstract}

\section{Background}

Renal impairment(RI) is a common complication of multiple myeloma. Few studies have been conducted to determine the association between the serum calcium concentration and the occurrence of RI in MM patients.

\section{Methods}

In this retrospective study, we included 568 patients with newly diagnosed MM who participated in an ongoing retrospective cohort study. The serum calcium concentrations and the presence of RI at baseline in MM patients were evaluated. Patient data were collected at baseline and multiple regression analyses were used to estimate independent relationships. We further used a two piecewise linear regression model to identify non-linear relationships.

\section{Results}

The serum calcium concentration was independent associated with the presence of RI and the serum creatinine levels in MM patients in basic or fully adjusted analyses. Hypercalcemia was independent associated with a high risk of RI occurrence in MM patients. The serum calcium concentration was significantly associated with the presence of RI in a non-linear relationship with a turning point of 2.3 $\mathrm{mmol} / \mathrm{L}$. There was a positive correlation between the serum calcium concentration and the presence of $\mathrm{RI}$ when the serum calcium concentrations was $>2.3 \mathrm{mmol} / \mathrm{L}(\mathrm{p}<0.05)$; however, these associations were no longer statistically significant when the serum calcium concentration was $<2.3 \mathrm{mmol} / \mathrm{L}$ in fully adjusted analyses ( $p>0.05)$. The test for interactions was not statistically significant.

\section{Conclusions}

The serum calcium concentration was independent associated with the presence of RI in patients with MM. There was a nonlinear relationship between the serum calcium concentration and the presence of RI. The serum calcium concentration was positively related with the presence of RI when the albuminadjusted serum calcium concentration was $>2.3 \mathrm{mmol} / \mathrm{L}$. Our study suggested that we should take measures to reduce the blood calcium concentration earlier rather than waiting for hypercalcemia to occur.

\section{Introduction}

Multiple myeloma (MM) is a clonal B-cell malignancy of the bone marrow that is associated with a variety of clinical manifestations, including hypercalcemia, renal impairment (RI), anemia, and bone disease. MM is the second most common hematologic malignancy and accounts for $1 \%$ of all malignancies (1). 
$\mathrm{RI}$ is a common complication of MM. Depending on the definition of RI (defined as a serum creatinine level $>2 \mathrm{mg} / \mathrm{dL}$ ), this complication is reported in $15-40 \%$ of patients with $\mathrm{MM}$. At the time of diagnosis, $30-40 \%$ of patients with MM have a serum creatinine level above the upper limit of normal and the majority have a serum creatinine $<4 \mathrm{mg} / \mathrm{dL}(2)$.

Despite promising evidence on hypercalcemia (defined as a serum calcium concentration $>11.5 \mathrm{mg} / \mathrm{dL}$ or $2.85 \mathrm{mmol} / \mathrm{L})$ as an important biomarker of MM RI (3-4),these studies lack details on the effect of the serum calcium concentration on the serum creatinine level and the presence of RI. No interaction and quantitative analyses were performed. Also the study lacks the exploration and presentation of a linear relationship between the serum calcium concentration with MM-related RI occurrence. Therefore, we propose a clinical hypothesis that there is a correlation between serum calcium concentration and MMrelated $\mathrm{RI}$, but an increase in serum calcium concentration will lead to MM-related RI before reaching hypercalcemia. So this study aimed to assess the a linear and non-linear relationship between the serum calcium concentration and the presence of RI within the Chinese population for early prevention of kidney damage. The influence of other risk factors, such as anemia, immunoglobulin levels, and light chain protein was also evaluated by using interaction and stratified analyses.

\section{Subjects And Methods}

In this single center retrospective study was on the basis of a subset of an ongoing retrospective cohort study, we collected clinical and hematological data for newly diagnosed MM patients at the First Affiliated Hospital of the Medical School at Zhejiang University from January 1, 2011 to June 1, 2017. Our study was approved by the Ethics Committee of the First Affiliated Hospital(Reference Number:20191380). Clinical data were retrieved electronically from the medical records of the General Hospital Registry and reviewed retrospectively. For MM patients with multiple admissions, only the first set of observation data was used, thus preserving the assumption of independence of observations.

\subsection{Participants}

The inclusion criteria were as follows: 1) newly diagnosed symptomatic MM patients without a history of prior chemotherapy for MM; 2) no history of other solid tumors; and 3) no radiotherapy.

The exclusion criteria were as follows: 1) no integrated data for effects, such as serum albumin and serum total calcium; and 2) a history of kidney disease, severe infection, liver disease, or autoimmune disease.

The specific details of enrollment and exclusion are shown in the following flow chart (Fig. 1).

\subsection{Evaluated indicators}

The following indicators were evaluated: 1) demographic characteristics (age, sex, and underlying disease [hypertension and diabetes]); 2) baseline data, including routine blood and serum biochemical testing, immunoglobulin concentrations, routine urinalysis, and other data pre-chemotherapy; 3 ) 
hypercalcemia, defined as a corrected serum calcium greater than an elevated serum calcium (> $2.85 \mathrm{mmol} / \mathrm{L}$ or $11.5 \mathrm{mg} / \mathrm{dL})$; 4 ) the presence of Rl, defined as a serum creatinine level ( $2 \mathrm{mg} / \mathrm{dL}$ or177 umol/L) at the time of diagnosis $[5,6] ; 5)$ ISS classification was used for staging all patients[7, 8].

When participants presented with hypoalbuminemia (albumin, $4 \mathrm{~g} / \mathrm{dL}$ ), the albumin-adjusted serum calcium was calculated using the following formula: albumin adjusted serum calcium $(\mathrm{mg} / \mathrm{dL})=$ serum calcium (mg/dL) + [0.8 × (4-albumin) $(\mathrm{g} / \mathrm{dL})][9-11]$.

\subsection{Statistical analysis}

Continuous data are expressed as the mean \pm standard deviation and median (interquartile range). The categorical variables are presented as a number or percentage. The difference between two groups was assessed using a Student's t-test, chi-square test, or Mann-Whitney $U$ test, as appropriate. The trends of variables were detected by the linear-by-linear chi-square test.

We then used a univariate linear regression model analyses to estimate the independent relationship between the albumin-adjusted serum calcium concentration and the risk of MM-related RI with an adjustment for potential confounders. Both non-adjusted and multivariate adjusted models are listed. According to the recommendation of the STROBE statement, we simultaneously showed the results of unadjusted, minimally adjusted, and fully adjusted analyses. Whether or not the covariances were adjusted was determined by the following principle: when added to this model, the matched odds ratio changed by at least $10 \%$. We further used a two piecewise linear regression model to identify the nonlinear relationship. If a nonlinear correlation existed, a two piecewise linear regression model was used to calculate the threshold effect of the calcium concentration on MM-related RI in terms of the smoothing plot. When the threshold level (i.e., turning point) was apparent on the smoothed curve, the inflection point was automatically calculated by the recursive method and the maximum model likelihood was used [12]. Subgroup analyses were performed using stratified linear regression models. The modification and interaction of the subgroup were inspected by the likelihood ratio test. Statistical analysis was performed using Empower States (www.empowerstats.com; X \& Y Solution, Inc., Boston, MA, USA) and R software (http://www.R-project.org). A P value $<0.05$ was considered significant.

\section{Results}

\subsection{Baseline characteristics}

Of the 602 participants, 33 were excluded from this study, thus leaving 568 subjects for data analysis (Fig. 1).

Based on a serum creatinine level $>2 \mathrm{mg} / \mathrm{dL}$ or $177 \mathrm{umol} / \mathrm{L}$, we observed that 155 of 568 patients(27.2\%)with newly diagnosed MM presented with the presence of $\mathrm{RI}$, this percentage was similar to the incidence of renal failure in patients.

The characteristics of the study population are listed in Table 1, and Fig. 2 shows the distribution of the mean albumin-adjusted serum calcium concentration based on the presence of RI. Using the definition of 
IMWG(International Myeloma Working Group), [please spell out with 1st use] $11.4 \%$ of the patients with symptomatic MM had hypercalcemia (i.e., a corrected serum calcium $\geq 11.5 \mathrm{mg} / \mathrm{dL}$ ) at the time of diagnosis. 
Table 1

Baseline Characteristics of participants

\begin{tabular}{|c|c|c|c|}
\hline & $\begin{array}{l}\text { No renal impairment } \\
\text { group }\end{array}$ & $\begin{array}{l}\text { Renal impairment } \\
\text { group }\end{array}$ & $\begin{array}{l}\mathrm{P} \text { - } \\
\text { value }\end{array}$ \\
\hline $\mathrm{N}$ & 414 & 154 & \\
\hline Age(year) & & & 0.182 \\
\hline$<70$ & $298(73.2 \%)$ & $104(67.5 \%)$ & \\
\hline$>=70$ & $109(26.8 \%)$ & $50(32.5 \%)$ & \\
\hline Gender & & & 0.556 \\
\hline Female & $163(39.7 \%)$ & $55(36.9 \%)$ & \\
\hline Male & $248(60.3 \%)$ & $94(63.1 \%)$ & \\
\hline Hypertension history & & & 0.007 \\
\hline No & $267(65.0 \%)$ & $81(52.6 \%)$ & \\
\hline Yes & $144(35.0 \%)$ & $73(47.4 \%)$ & \\
\hline Diabetes history & & & 0.625 \\
\hline 0 & $377(92.2 \%)$ & $140(90.9 \%)$ & \\
\hline Yes & $32(7.8 \%)$ & $14(9.1 \%)$ & \\
\hline serum creatinine level(umol/L) & $84.6 \pm 30.4$ & $453.5 \pm 299.3$ & 0.001 \\
\hline eGFR(ml/min) & $83.8 \pm 28.2$ & $15.1 \pm 8.9$ & 0.001 \\
\hline Urinary kappa light chain $(\mathrm{mg} / \mathrm{dl})$ & $325.8 \pm 1123.9$ & $322.3 \pm 718.3$ & 0.003 \\
\hline Urinary lamda light chain $(\mathrm{mg} / \mathrm{dl})$ & $109.3 \pm 283.7$ & $385.2 \pm 889.9$ & 0.001 \\
\hline Serum albumin(g/l) & & & 0.011 \\
\hline$<35$ & $212(51.6 \%)$ & $61(39.6 \%)$ & \\
\hline$>=35$ & $199(48.4 \%)$ & $93(60.4 \%)$ & \\
\hline Serum globulin(g/l) & $53.3 \pm 25.7$ & $40.0 \pm 24.1$ & 0.001 \\
\hline Hemoglobin(g/l) & & & 0.001 \\
\hline$<100$ & $238(58.3 \%)$ & 132 (85.7\%) & \\
\hline
\end{tabular}

Note:

ISS stage: international staging system 


\begin{tabular}{|llll|}
\hline & $\begin{array}{l}\text { No renal impairment } \\
\text { group }\end{array}$ & $\begin{array}{l}\text { Renal impairment } \\
\text { group }\end{array}$ & $\begin{array}{l}\text { P- } \\
\text { value }\end{array}$ \\
\hline$>=100$ & $170(41.7 \%)$ & $22(14.3 \%)$ & 0.001 \\
\hline $\begin{array}{l}\text { albumin-adjusted serum } \\
\text { calcium(mmol/I) }\end{array}$ & $381(92.3 \%)$ & $121(78.6 \%)$ & \\
\hline$<2.85$ & $32(7.7 \%)$ & $33(21.4 \%)$ & 0.002 \\
\hline$>=2.85$ & & & \\
\hline Lactate dehydrogenase(u/l) & $316(92.4 \%)$ & $92(82.1 \%)$ & \\
\hline$<300$ & $26(7.6 \%)$ & $20(17.9 \%)$ & \\
\hline$>=300$ & & $4(3.6 \%)$ & \\
\hline Serum beta 2 microglobulin(ug/l) & $157(43.9 \%)$ & $107(96.4 \%)$ & \\
\hline$<3500$ & $201(56.1 \%)$ & & \\
\hline$>=3500$ & & $3(1.9 \%)$ & $151(98.1 \%)$ \\
\hline ISS stage & $88(21.3 \%)$ & & \\
\hline ISS-stage -1 & $325(78.7 \%)$ & & \\
\hline ISS-stage $-2-3$ & & & \\
\hline Note: & & & \\
\hline ISS stage: international staging system & & & \\
\hline
\end{tabular}

Table I shows the patient and disease features among patients with or without the presence of RI (a serum creatinine $>2 \mathrm{mg} / \mathrm{dL}$ or $177 \mu \mathrm{mol} / \mathrm{L}$ ). The two age groups were comparable with respect to sex distribution, urine total light chain concentration, and ISS stage. There were significant differences in Hemoglobin, [please spell out with 1st use] hypercalcemia, higher ISS stage, and serum creatinine > $2 \mathrm{mg} / \mathrm{dL}$ or $177 \mu \mathrm{mol} / \mathrm{L}$, Lactate dehydrogenase (LDH), and serum beta-2 microglobulin levels. In contrast, there was no significant difference in age, sex, and history of diabetes mellitus between patients with RI compared with the control group.

\subsection{Univariate analysis}

Univariate logistic regression analyses between the presence of RI and multiple parameters were performed (Table 2). Based on univariate logistic regression, the results of univariate analysis showed that the corrected serum calcium concentration, anemia, platelet count, ISS stage, and low albumin, serum LDH, and serum beta-2 microglobulin levels had a significant association with Myeloma-Related RI 
in patients with MM. We also found that age, sex, diabetes mellitus, and a history of diabetes mellitus were not associated with MM-related RI in patients with MM. 
Table 2

Univariate analysis for the presence of RI

\begin{tabular}{|c|c|c|c|}
\hline & Statistics & Effect size $(95 \% \mathrm{Cl})$ & $P$ value \\
\hline Age(year) & $63.1 \pm 10.2$ & $0.5(-1.4,2.3)$ & 0.611 \\
\hline \multicolumn{4}{|l|}{ Gender } \\
\hline female & $218(38.9 \%)$ & ref & \\
\hline male & $343(61.1 \%)$ & $20.7(-13.0,54.4)$ & 0.230 \\
\hline Urinary kappa light chain(mg/dl) & $187.4 \pm 544.3$ & $0.1(0.0,0.1)$ & 0.003 \\
\hline Urinary lamda light chain(mg/dl) & $324.8 \pm 1025.7$ & $0.0(-0.0,0.0)$ & 0.330 \\
\hline Hemoglobin(g/l) & $91.1 \pm 25.5$ & $-2.1(-2.8,-1.4)$ & 0.001 \\
\hline PLC & $169.3 \pm 78.2$ & $-0.2(-0.5,0.0)$ & 0.053 \\
\hline Serum albumin $(\mathrm{g} / \mathrm{l})$ & $35.1 \pm 7.9$ & $2.0(-0.4,4.3)$ & 0.107 \\
\hline Serum globulin(g/l) & $49.7 \pm 25.9$ & $-1.9(-2.6,-1.2)$ & 0.001 \\
\hline serum calcium (mmol/l) & $2.3 \pm 0.3$ & $99.1(46.1,152.2)$ & 0.001 \\
\hline albumin-adjusted serum calcium(mmol/l) & $2.4 \pm 0.4$ & $64.4(14.0,114.7)$ & 0.012 \\
\hline Serum beta 2 microglobulin (ug/l) & $8001.6 \pm 7502.9$ & $0.0(0.0,0.0)$ & 0.001 \\
\hline LDH u/l & $216.6 \pm 295.1$ & $0.0(-0.0,0.1)$ & 0.301 \\
\hline \multicolumn{4}{|l|}{ ISS } \\
\hline ISS-stage - 1 & $91(16.0 \%)$ & ref & \\
\hline ISS-stage - 2-3 & 477 (84.0\%) & $120.7(70.6,170.8)$ & 0.001 \\
\hline \multicolumn{4}{|l|}{ Gender. } \\
\hline female & $218(38.9 \%)$ & ref & \\
\hline male & $343(61.1 \%)$ & $20.7(-13.0,54.4)$ & 0.230 \\
\hline \multicolumn{4}{|l|}{ Diabetes history } \\
\hline 0 & $518(91.8 \%)$ & ref & \\
\hline Yes & $46(8.2 \%)$ & $34.1(-34.7,103.0)$ & 0.332 \\
\hline \multicolumn{4}{|l|}{ Hypertension history } \\
\hline No & $348(61.5 \%)$ & ref & \\
\hline Yes & 218 (38.5\%) & $57.6(19.2,95.9)$ & 0.003 \\
\hline
\end{tabular}




\subsection{The results of relationship between serum calcium concentrations and the presence of RI}

We used a univariate linear regression model to evaluate the association between the corrected albuminadjusted serum calcium concentration and the serum creatinine level and the presence of RI. The nonadjusted and adjusted models are shown in Table 3. In the crude model, the albumin-adjusted serum calcium concentration had a positive independent correlation with the presence of $\mathrm{RI}(\beta=2.8,95 \%$ confidence interval [Cl]: 1.7-4.6, $\mathrm{P}<0.001)$. In the minimally adjusted model (adjusted for age and sex), there were no apparent changes $(\beta=2.9), 95 \% \mathrm{Cl}: 1.7-4.7, \mathrm{P}<0.001)$. We also detected a significant connection in the fully adjusted model $(\beta=3.4,95 \% \mathrm{Cl}: 1.7-6.7, \mathrm{P}<0.001)$. For the purpose of sensitivity analysis, we also designated the albumin-adjusted serum calcium concentration as a categorical variable (with or without hypercalcemia), and found that the same trend was observed as well (3.4,95\% Cl:1.6, 7.2, $P<0.001)$. Hypercalcemia was independent associated with a high risk of RI occurrence in MM patients. This result also showed that the albumin-adjusted serum calcium concentration and hypercalcemia were independent associated with the serum creatinine level after adjusting for age, sex, diabetes mellitus, a history of diabetes mellitus, Hemoglobin, the serum albumin level, globulin level, platelet count, urine light chain concentration,LDH concentration】and ISS stage in patients with MM ( Table 3). 
Table 3

Relationship between serum calcium and serum creatinine level and the presence of RI in different models

Variable

albumin-

adjusted serum

calcium

levle(mmol/l)

No adjusted

serum

calcium

level $(\mathrm{mmol} / \mathrm{l})$

albumin-

adjusted

serum

calcium(mmol/l)

$<2.85$

$>=2.85$
0

90.9

(32.6,

149.3)

0.002 serum creatinine level

\begin{tabular}{|c|c|}
\hline $\begin{array}{l}\text { Crude } \\
\text { model }\end{array}$ & $\begin{array}{l}\text { Minimally } \\
\text { adjusted }\end{array}$ \\
\hline$(\beta$, & model $(\beta$, \\
\hline $\begin{array}{l}95 \% \mathrm{Cl} \text {, } \\
\text { P) }\end{array}$ & $95 \% \mathrm{Cl}, \mathrm{P})$ \\
\hline
\end{tabular}

The occurrence of RI

$\begin{array}{llll}\begin{array}{l}\text { Fully adjusted } \\ \text { model }(\beta, 95 \% \mathrm{Cl}, \mathrm{P})\end{array} & \begin{array}{l}\text { Crude } \\ \text { model } \\ (\beta,\end{array} & \begin{array}{l}\text { Minimally } \\ \text { adjusted } \\ \text { model }(\beta,\end{array} & \begin{array}{l}\text { Fully } \\ \text { adjusted } \\ \text { model }\end{array} \\ & 95 \% \mathrm{Cl}, & 95 \% \mathrm{Cl}, \mathrm{P}) & (\beta, \\ & \mathrm{P}) & & 95 \% \mathrm{Cl},\end{array}$

P)

$\begin{array}{llllll}64.4 & 71.5(27.2, & 68.0(22.9,113.2) & 2.8 & 2.9(1.7, & 3.4(1.7, \\ (14.0, & 115.7) 0.002 & 0.003 & (1.7, & 4.7) 0.001 & 6.7) \\ 114.7) & & & 4.6)^{\prime} & & 0.001 \\ 0.012 & & & & \\ & & & & & \\ 99.1 & 103.6(56.7, & 68.0(22.9,113.2) & 4.4 & 4.5(2.6, & 3.4(1.7, \\ (46.1, & 150.5)< & 0.003 & (2.6, & 7.7) 0.001 & 6.7) \\ 152.2) & 0.001 & & 7.6) & & 0.001 \\ 0.001 & & & 0.001 & & \end{array}$

Non-adjusted model adjust for: None

Adjust I model adjust for: AGE; Gender.; hypertension history; diabetes history

Adjust II model adjust for: AGE; Gender.; hypertension history; diabetes history LDH, Urinary kappa light chain, Urinary lamda light chain,HB,PLT,serum globulin and ISS-stage, serum albumin and serum beta 2 microglobulin

\subsection{The analyses of non-linear relationship between serum calcium concentrations and the presence of RI}

Because the albumin-adjusted serum calcium concentration was a continuous variable, an analysis of the nonlinear relationship was necessary. In the present study (Fig. 3), we showed that the relationship 
between the albumin-adjusted serum calcium concentration and the presence of RI in MM was nonlinear (after adjusting for age, sex, hypertension history; diabetes history, LDH, urinary kappa light chain concentration, urinary lambda light chain concentration, Hemoglobin, platelet count, serum globulin concentration, and ISS stage (international staging system ) including serum albumin and serum beta- 2 microglobulin. Based on the two piecewise linear regression model, we calculated the inflection point about the serum calcium concentration to be $2.3 \mathrm{mmol} / \mathrm{L}$. We observed no relationship between the albumin-adjusted serum calcium concentration and MM-related RI occurrence on the left of the inflection point $(0.1,0-2.3$, and 0.15 ; Table 4$)$. However, on the right of the inflection point, the effect size, $95 \% \mathrm{Cl}$, and $P$ value were $4.4,1.9-10.2$ and 0.001 , respectively. The result showed that the albumin-adjusted serum calcium concentration had a significant positive association with RI occurrence in MM patients when the -adjusted serum calcium concentration was $>2.3 \mathrm{mmol} / \mathrm{L}$ (Table 4 ).

Table 4

Threshold Effect Analysis of serum calcium level and the presence of RI using Piece-wise Linear Regression

\begin{tabular}{ll} 
Model & Result $[\boldsymbol{\beta}(95 \% \mathrm{Cl}) \mathbf{P}$ valu \\
\hline Model I & \\
\hline one-line linear regression model & $2.8(1.4,5.6) 0.004$ \\
\hline Model II & \\
\hline turning point & 2.3 \\
\hline Group1 < 2.3 correlation coefficient $(\beta 1)$ & $0.1(0.0,2.3) 0.150$ \\
\hline Group2 > 2.3, correlation coefficient $(\beta 1)$ & $4.4(1.9,10.2)<0.001$ \\
\hline predictive value of RI at turning point & $-1.4(-1.7,-1.1)$ \\
\hline a log likelihood ratio test & 0.027
\end{tabular}

Note:

Effect: albumin-adjusted serum calcium level Cause: Myeloma-Related RI

Adjusted for AGE; Gender.; hypertension history; diabetes history LDH, Urinary kappa light chain, Urinary lamda light chain,HB,PLT, Serum globulin and ISS-stage, serum albumin ,serum beta 2 microglobulin

As shown in Table 5, the test for interactions was not statistically significant for age, sex, Hemoglobin, $\mathrm{LDH}$, and serum albumin ( $P$ for interaction $>0.05$; Table 5 ). 
Table 5

Effect size of serum calcium on serum creatinine level in prespecified and exploratory subgroups in each subgroup

\begin{tabular}{|c|c|c|c|c|}
\hline Characteristic & $\begin{array}{l}\text { No. of } \\
\text { participants }\end{array}$ & OR $(95 \% \mathrm{Cl})$ & $\begin{array}{l}\mathrm{P} \text { - } \\
\text { value }\end{array}$ & $\begin{array}{l}\text { P for } \\
\text { interaction }\end{array}$ \\
\hline Age (year) & & & & 0.1605 \\
\hline$<70$ & 123 & $56.4(5.6,107.1)$ & 0.0302 & \\
\hline$\geq 70$ & 324 & $128.9(35.4,222.4)$ & 0.0073 & \\
\hline Sex & & & & 0.4668 \\
\hline Male & 343 & $58.6(1.2,115.9)$ & 0.0463 & \\
\hline Female & 218 & $90.8(19.8,161.7)$ & 0.0127 & \\
\hline $\mathrm{HB}$ & & & & 0.4735 \\
\hline$<100 \mathrm{~g} / \mathrm{l}$ & 371 & $79.5(28.4,130.6)$ & 0.0025 & \\
\hline$\geq 100 \mathrm{~g} / \mathrm{l}$ & 192 & $41.6(-53.7,137.0)$ & 0.379 & \\
\hline Hypertension history & & & & 0.5495 \\
\hline No & 348 & $66.1(10.5,121.7)$ & 0.0204 & \\
\hline Yes & 218 & $92.9(16.3,169.5)$ & 0.0181 & \\
\hline Serum albumin & & & & 0.1182 \\
\hline$>35 \mathrm{~g} / \mathrm{l}$ & & $47.3(-8.7,103.3)$ & 0.0989 & \\
\hline$<35 \mathrm{~g} / \mathrm{l}$ & & $-9.1(-57.9,39.7)$ & 0.7154 & \\
\hline Diabetes & & & & 0.0270 \\
\hline No & & $90.6(42.3,139.0)$ & 0.0003 & \\
\hline Yes & & $-93.0(-253.4,67.3)$ & 0.2564 & \\
\hline Lactate dehydrogenase & & & & 0.3717 \\
\hline$<300 \mathrm{u} / \mathrm{l}$ & & $80.8(30.0,131.6)$ & 0.0020 & \\
\hline$>300 \mathrm{u} / \mathrm{l}$ & & $24.9(-92.3,142.2)$ & 0.6770 & \\
\hline
\end{tabular}

Note 1:Above model adjusted for AGE; Gender.; hypertension history; diabetes history LDH, Urinary kappa light chain, Urinary lamda light chain,HB,PLT,Serum globulin and ISS-stage,serum albumin and serum beta 2 microglobulin

Note 2:In each case, the model is not adjusted for the stratification variable 


\begin{tabular}{|c|c|c|c|c|}
\hline Characteristic & $\begin{array}{l}\text { No. of } \\
\text { participants }\end{array}$ & OR $(95 \% \mathrm{Cl})$ & $\begin{array}{l}P \text { - } \\
\text { value }\end{array}$ & $\begin{array}{l}\text { P for } \\
\text { interaction }\end{array}$ \\
\hline $\begin{array}{l}\text { Serum beta } 2 \\
\text { microglobulin }\end{array}$ & & & & 0.5245 \\
\hline$<3500 \mathrm{ug} / \mathrm{l}$ & & $\begin{array}{l}23.0(-105.5, \\
151.5)\end{array}$ & 0.7261 & \\
\hline$>3500$ ug/l & & $65.1(16.3,113.9)$ & 0.0094 & \\
\hline \multicolumn{5}{|c|}{$\begin{array}{l}\text { Note 1:Above model adjusted for AGE; Gender.; hypertension history; diabetes history LDH, Urinary } \\
\text { kappa light chain, Urinary lamda light chain,HB,PLT,Serum globulin and ISS-stage,serum albumin anc } \\
\text { serum beta } 2 \text { microglobulin }\end{array}$} \\
\hline \multicolumn{5}{|c|}{ Note 2:In each case, the model is not adjusted for the stratification variable } \\
\hline
\end{tabular}

\section{Discussion}

In this study we demonstrated that the serum calcium concentration was associated with the serum creatinine level and MM-related RI occurrence in Chinese patients with newly diagnosed MM in basic or fully adjusted analyses. Hypercalcemia was associated with a high risk of RI occurrence in MM patients. We also showed a nonlinear relationship between the albumin-adjusted serum calcium concentration and the presence of RI in MM. Our results revealed a threshold effect of the albumin-adjusted serum calcium concentration based on the presence of RI assessment in MM. Different correlations of albumin-adjusted serum calcium concentrations and the presence of RI in MM were found on the left and right sides of the inflection point (albumin-adjusted serum calcium concentration $=2.3 \mathrm{mmol} / \mathrm{L}$ ). The albumin-adjusted serum calcium concentration, as assessed at baseline, was not associated with RI occurrence on the left side of the inflection point, but the association on the right side of the inflection point was positively and statistically significant. The result showed that the albumin-adjusted serum calcium concentration had a significant positive association with RI occurrence in MM patients when the albumin-adjusted serum calcium concentration was $>2.3 \mathrm{mmol} / \mathrm{L}$.

This is the first epidemiological study to provide clear evidence of a nonlinear association between the serum albumin-adjusted serum calcium concentration and the presence of RI in patients with MM.

$\mathrm{RI}$ is a common feature of MM and may provide a clue to diagnosis, yet cause a major management problem. Depending on the definition of RI, this complication occurs in $20-40 \%$ of newly diagnosed patients with MM (13-15). When a serum creatinine level > $2 \mathrm{mg}$ per $100 \mathrm{~mL}$ was used to define Rl, approximately $20 \%$ of patients with MM have RI at the time of diagnosis. we observed that 155 of 568 patients(27.2\%)with newly diagnosed MM presented with RI in this study.

The 2-year all-cause mortality of patients with end-stage renal disease due to MM-related RI occurrence was $58 \%$ versus $31 \%$ in all other patients (16). MM-related RI occurrence in MM results primarily from the toxic effects of monoclonal light chains on the kidney, such as cast nephropathy, as well as other 
contributing factors, such as hypercalcemia, hyperuricemia, and myeloma cell infiltration or hyperviscosity have rarely been reported $(17,18)$.

Hypercalcemia(defined as a serum calcium concentration $>11.5 \mathrm{mg} / \mathrm{dL}$ or $2.85 \mathrm{mmol} / \mathrm{L}$ )) is as the second most common cause of renal failure in patients with MM, except free light chains $(19,20)$. Some researchers are of the opinion that hypercalcemia and/or Bence-Jones proteinuria explain renal failure in $97 \%$ of patients (3). Hypercalcemia interferes with renal function and impairs the renal concentrating ability, causes vasoconstriction of the renal vasculature and enhances diuresis, which may result in hypovolemia and pre-renal azotemia. Concentrated urine and reduced urine flow enhance cast formation, thus leading to further renal damage $(19,20)$.

Hypercalcemia is a defining characteristic of symptomatic MM, and observed approximately in $15 \%$ of newly diagnosed patients $(4,21)$. Our cohort came from China and showed a low incidence of hypercalcemia $(11.4 \%)$.

Hypercalcemia is an important cause of renal failure, but whether or not hypercalcemia is an independent risk factor for loss of renal function is controversial. Zagouri et al. (7) reported that hypercalcemia is associated with a lower Estimating Glomerular Filtration Rate (eGFR) as an independent risk factor, but logistic regression analysis was then performed at the University of Athens School of Medicine, which showed that creatinine is independently associated with ISS stage and Bence-Jones proteinuria (21).Our study showed hypercalcemia was independently associated with a high risk of RI occurrence in MM patients.

Colleagues should also pay attention to a problem which is very important to correct the serum calcium level with albumin. Most of the protein-bound calcium is bound to albumin, while the remainder is complexed to globulins. Disorders that lower serum albumin will lower total serum calcium, but have a lesser effect on the ionized calcium concentration (9-11). The guidelines for MM also recommend the use of the albumin-adjusted serum calcium concentration as a research indicator (6).

The main problem of the existing researchs is that these studies were only concerned about the effects of hypercalcemia on MM-related RI occurrence $(4,7,21)$. At the same time, the calcium level in these studies were not corrected by serum albumin, and till this moment few similar studies were conducted to investigate the association between the serum calcium concentration and MM-related RI occurrence in patients with MM. Therefore, we propose a clinical hypothesis that there is a correlation between serum calcium concentration and MM-related RI, but an increase in serum calcium concentration will lead to MM-related RI before reaching hypercalcemia.

The occurrence of renal damage is closely related to the serious prognosis of MM. Our study confirmed that the serum calcium concentration was associated with the serum creatinine level and the occurrence of MM-related RI ,and hypercalcemia is an independent factor in renal damage in Chinese patients with newly diagnosed MM. More importantly, we found that there is a nonlinear relationship between the albumin-adjusted serum calcium concentration and the occurrence of RI. There was a positive correlation 
between the serum calcium concentration and the occurrence of RI when the serum calcium concentration was $>2.3 \mathrm{mmol} / \mathrm{L}(\mathrm{p}<0.05)$; however, these associations were no longer statistically significant when the serum calcium concentrations was $\langle 2.3 \mathrm{mmol} / \mathrm{L}$ in fully adjusted analyses $(p>$ 0.05). Our study suggested that we should take measures to lower the blood calcium level to prevent kidney damage when the albumin-adjusted serum calcium concentration exceeds $2.3 \mathrm{mmol} / \mathrm{L}$ rather than after the occurrence of hypercalcemia.

The limitations of our study included the observational design, retrospective ascertainment of the serum calcium concentration, the serum creatinine level at a single time point late during the course of newly diagnosed MM, and the potential misclassification of study measurements.

\section{Conclusions}

In conclusion, our study showed that the serum calcium concentration was independent associated with the occurrence of $\mathrm{RI}$ and serum creatinine level in Chinese patients with newly diagnosed MM. There was a nonlinear relationship between the serum calcium concentration and the occurrence of RI. The serum calcium concentration was positively related with the occurrence of RI the when albumin-adjusted serum calcium concentration was $>2.3 \mathrm{mmol} / \mathrm{L}$. Our study suggested that we should take measures to reduce blood calcium earlier, instead of waiting for hypercalcemia to occur.

\section{Abbreviations}

multiple myeloma:MM; Renal impairment:Rl; IMWG:International Myeloma Working Group; ISS stage:international staging system ; Lactate dehydrogenase:LDH; Glomerular Filtration Rate:GFR; Cls:Confidence intervals.

\section{Declarations}

\section{Acknowledgements}

The authors gratefully express appreciation to the efforts and contributions of the doctors.

\section{Availability of data and materials}

The datasets used and/or analysed during the current study are available from the corresponding author on reasonable request.

\section{Funding}

This work was supported by grant LY19H050007 from Zhejiang Natural Science Foundation and grant 2016KYA087 Zhejiang Medical and Health Science and Technology Project

\section{Author Contributions}


This study was designed and supervised by Jianghua Chen and Jun Cheng. Data analyses were performed by Yi Zhao, XiayuLi,RongLv,HengLi. Data interpretation and manuscript writing received contributions from all authors. All authors read and approved the final manuscript.

\section{Ethics approval and consent to participate}

This study was approved by the Clinical Research Ethics Committee of the First Affiliated Hospital of Zhejiang University. The institutional review board approved this procedure. All participants gave written informed consent before inclusion in the study.

\section{Consent for publication}

All authors have seen and approved the manuscript being submitted.

\section{Competing interests}

The authors declare that they have no competing interests.

\section{References}

1.Ludwig H, Miguel JS, Dimopoulos MA, et al: International Myeloma Working Group recommendations for global myeloma care. Leukemia 2014; 28: 981-992

2.Knudsen LM, Hjorth M, Hippe E: Renal failure in multiple myeloma: Reversibility and impact on the prognosis. Nordic Myeloma Study Group. Eur J Haematol 65:175-181, 2000

3.Abbott KC, Agodoa LY: Multiple myeloma and light chain-associated nephropathy at end-stage renal disease in the United States: Patient characteristics and survival. Clin Nephrol 56:207-210, 2001

4.Alexanian R, Barlogie B, Dixon D: Renal failure in multiple myeloma: Pathogenesis and prognostic implications. Arch Intern Med 150:1693-1695, 1990

5.Dimopoulos MA, Kastritis E, Rosinol L, et al: Pathogenesis and treatment of renal failure in multiple myeloma. Leukemia 22:1485-1493, 2008

6.Barlogie B, Dixon D: Renal failurein multiple myeloma: Pathogenesis and prognostic implications. Arch Intern Med 150:1693-1695, 1990

7 .Flora Zagouri, Efstathios Kastritis, Athanasios Zomas, Evangelos Terpos, Eirini Katodritou, Argiris Symeonidis, Sosana Delimpasi, Anastasia Pouli, Theodoros P Hypercalcemia remains an adverse prognostic factor for newly diagnosed multiple myeloma patients in the era of novel anti-myeloma therapies. Eur J Haematol. 2017 Nov;99(5):409-414

8 Rajkumar SV, Dimopoulos MA, Palumbo A, Blade J, Merlini G, Mateos MV, et al.International Myeloma Working Group updated criteria for the diagnosis of multiple myeloma. Lancet Oncol 2014;15(12):e538- 
9.Meletios A. Dimopoulos, Pieter Sonneveld, Nelson Leung, Giampaolo Merlini, Heinz Ludwig, Efstathios Kastritis, International Myeloma Working Group Recommendations for the Diagnosis and Management of Myeloma-Related Renal Impairment J Clin Oncol.2016 May 1;34(13):1544-57

10.Masson I, Flamant M, Maillard N, et al: MDRD versus CKD-EPI equation to estimate glomerular filtration rate in kidney transplant recipients. Transplantation 95:1211-1217, 2013

11.Inker $\mathrm{LA}$, Schmid $\mathrm{CH}$, Tighiouart $\mathrm{H}$, et al: Estimating glomerular filtration rate from serum creatinine and cystatin C. N Engl J Med 367:20-29,2012

12.Bushinsky DA, Monk RD. Electrolyte quintet: calcium. Lancet 1998;352:306-311

13. Walker MD, Dempster DW, McMahon DJ, et al. Effect of renal function on skeletal health in primary hyperparathyroidism. J Clin Endocrinol Metab 2012;97:1501-1507

14. Calvi LM, Bushinsky DA. When is it appropriate to order an ionized calcium? J Am Soc Nephrol 2008;19:1257-1260)

15.Kernan WN, Viscoli CM, Brass LM, Broderick JP, Brott T, Feldmann E, et al.Phenylpropanolamine and the risk of hemorrhagic stroke. N Engl J Med.2000;343:1826-32.

16.Riccardi A, Gobbi PG, Ucci G, et al: Changing clinical presentation of multiple myeloma. Eur J Cancer 27:1401-1405, 1991

17.Abbott KC, Agodoa LY: Multiple myeloma and light chain-associated nephropathy at end-stage renal disease in the United States: Patient characteristics and survival. Clin Nephrol 56:207-210, 2001

18.Tsakiris DJ, Stel VS, Finne P, et al: Incidence and outcome of patients starting renal replacement therapy for end-stage renal disease due to multiple myeloma or light-chain deposit disease: An ERAEDTA Registry study. Nephrol Dial Transplant 25:1200-1206, 2010

19.Dimopoulos MA, Kastritis E, Rosinol L, et al:Pathogenesis and treatment of renal failure in multiple myeloma. Leukemia 22:1485-1493, 2008

20. Hutchison CA, Batuman V, Behrens $\mathrm{J}$, et al: The pathogenesis and diagnosis of acute kidney injury in multiple myeloma. Nat Rev Nephrol 8:43-51, 2012

21.Eleutherakis-Papaiakovou V1, Bamias A, Gika D, Simeonidis A, Pouli A, Anagnostopoulos A Renal failure in multiple myeloma: incidence, correlations, and prognostic significance Leuk Lymphoma.2007 Feb;48(2):337-41

\section{Figures}


Figure 1. Flow diagram of participants

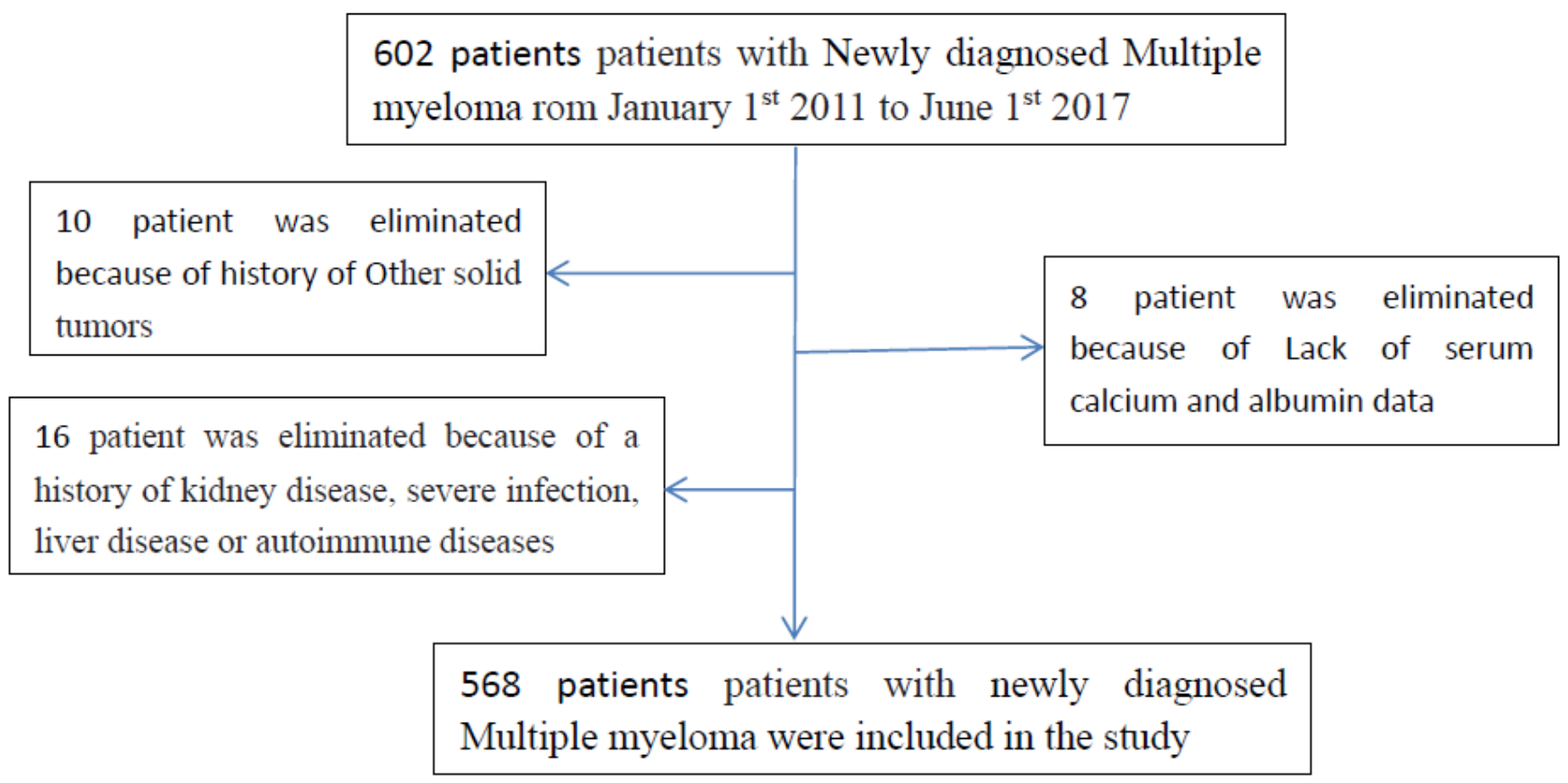

Figure 1

Flow diagram of participants 


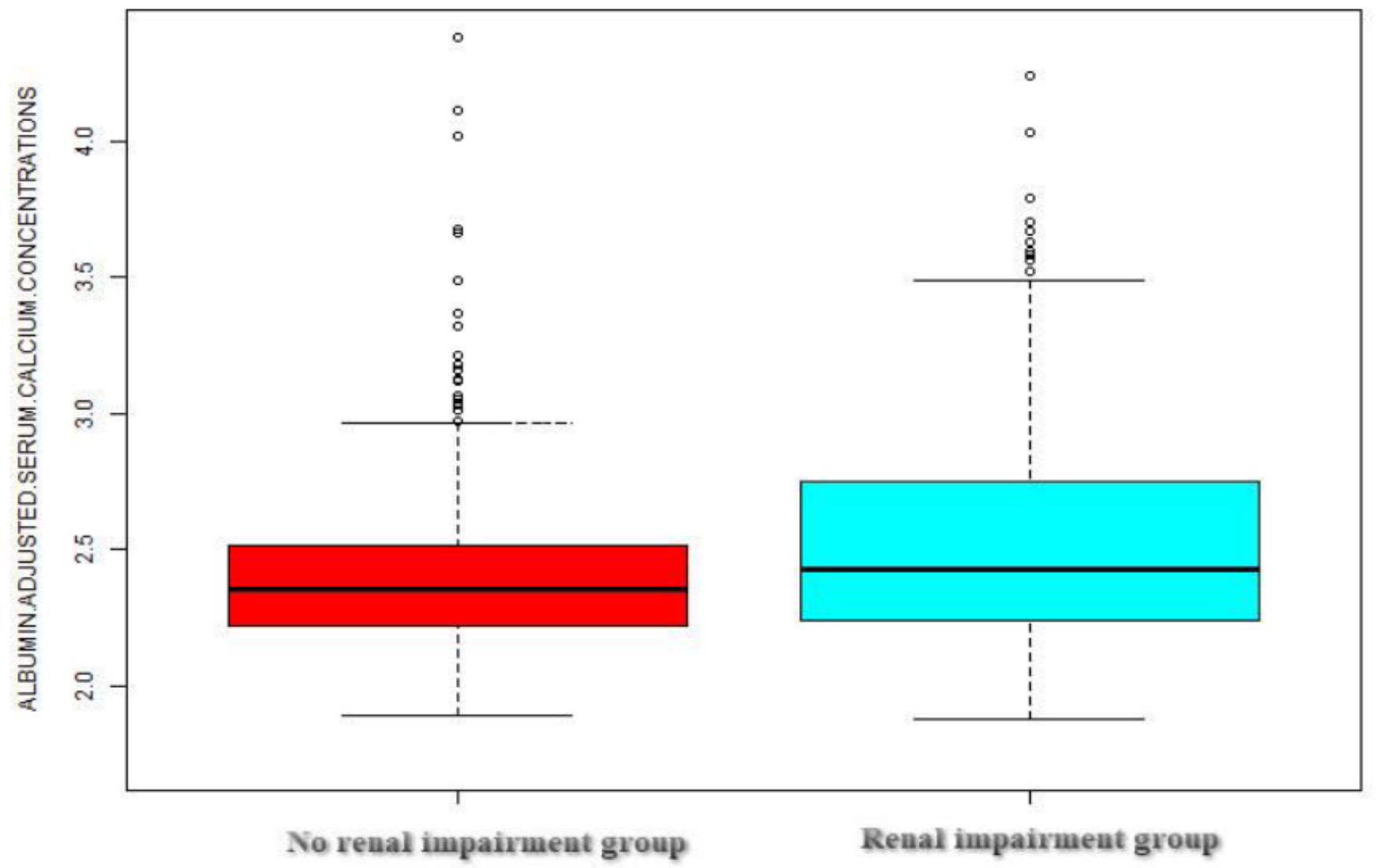

\section{Figure 2}

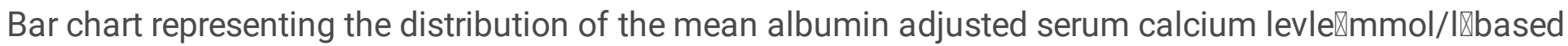
on the presence of renal impairment(defined as a serum creatinine level $>2 \mathrm{mg} / \mathrm{dL}$ ) according to the International Myeloma Working Group. 


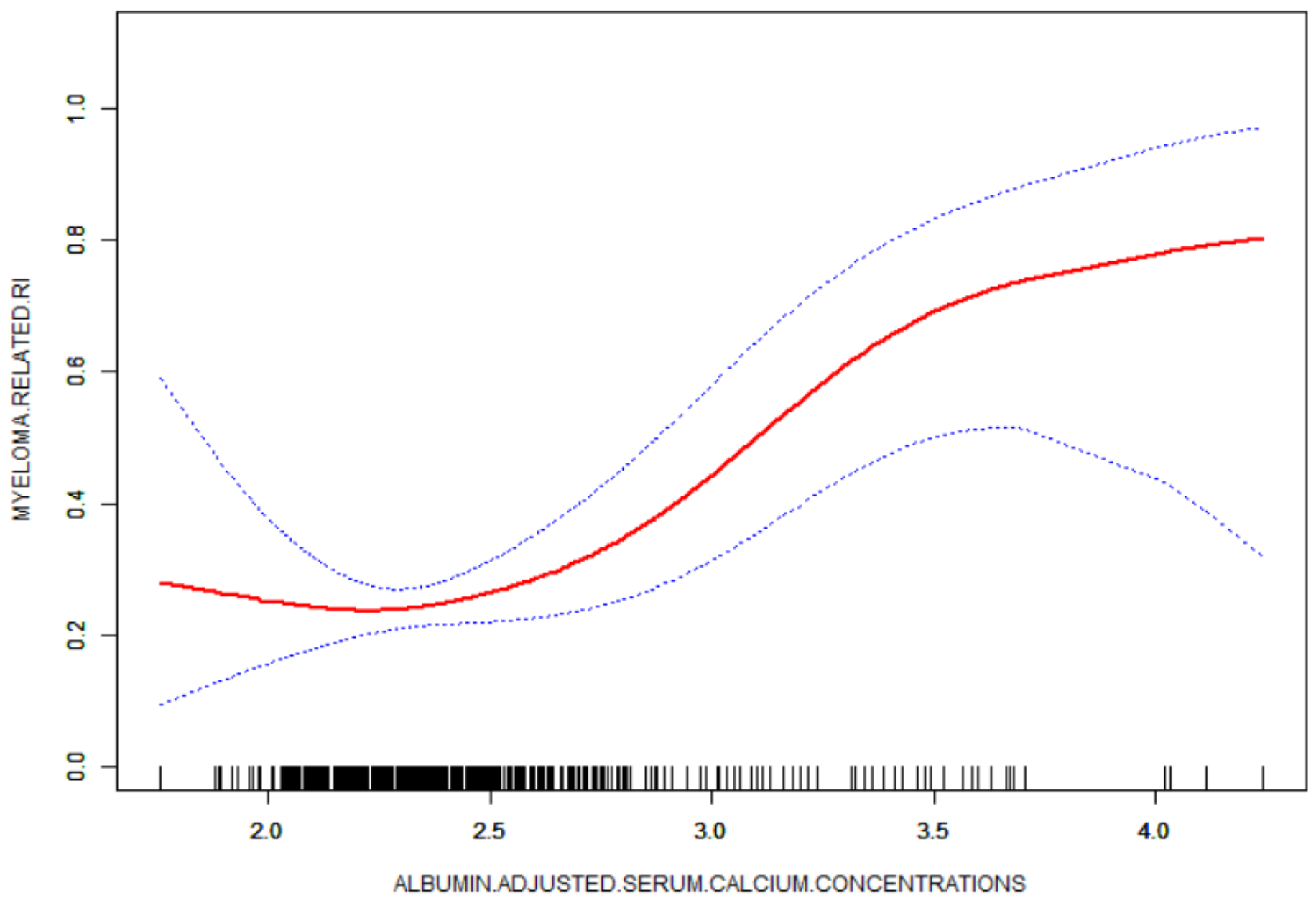

\section{Figure 3}

The relationship between serum calcium level and the occurrence of Myeloma-Related RI. A nonlinear relationship between them was detected after adjusting for AGE; Gender, hypertension history; diabetes history LDH, Urinary kappa light chain, Urinary lamda light chain,HB,PLT,Serum globulin and ISS-stage, serum albumin , serum beta 2 microglobulin 